\title{
Safe Synthesis of Alkylhydroxy and Alkylamino Nitramines
}

\author{
Simen Antonsen ${ }^{1}$, Marius Aursnes ${ }^{1}$, Harrison Gallantree-Smith ${ }^{1}$, Christian Dye ${ }^{2,3}$ \\ and Yngve Stenstrøm ${ }^{1, *}$ \\ 1 Department of Chemistry, Biotechnology and Food Science, Norwegian University of Life Sciences, \\ P.O. Box 5003, NO-1433 Ås, Norway; simen.antonsen@nmbu.no (S.A.); \\ marius.aursnes@farmasi.uio.no (M.A.); harrison.gallantree-smith@nmbu.no (H.G.-S.) \\ 2 Institute for Energy Technology (IFE), NO-2027 Kjeller, Norway; Christian.Dye@ife.no \\ 3 Norwegian Institute for Air Research (NILU), NO-2027 Kjeller, Norway \\ * Correspondence: yngve.stenstrom@nmbu.no; Tel.: +47-672-32-559 \\ Academic Editor: Derek J. McPhee \\ Received: 11 November 2016; Accepted: 12 December 2016; Published: 16 December 2016
}

Abstract: Three different protocols for the syntheses of hydroxyalkylnitramines are presented and compared. Safety issues regarding the synthesis of nitramines are also discussed.

Keywords: nitramines; safe method; carbon capture; AMP; MEA

\section{Introduction}

Carbon capture of today has been implemented as an important tool for controlling the greenhouse effect on our planet. Several technologies for carbon capture and storage (CCS) have been developed, but amine-based technologies have been found to be the most promising [1]; especially the aminoalkanols, such as 2-amino-1-ethanol (MEA; 1) and 2-amino-2-methyl-1-propanol (AMP; 2) [2]. The use of MEA for such a purpose has been implemented on a large scale by Statoil in the North Sea, since the mid-1990s [3]. One major drawback associated with the amine-based CCS is the formation of harmful byproducts: i.e., the reaction of the amino group to give nitramines and nitrosamines [4]. This has spurred a new interest in these compounds [5-10]. A recent review summarizes the hazard assessment of these as byproducts of amine-based CCS [7]: nitramines are less carcinogenic than the corresponding nitrosamine [11] and formed in lower concentration in $\mathrm{CO}_{2}$ capture systems [3,12], but they are more persistent in the environment due to the lack of sunlight photolysis $[9,13]$. However, the conclusion is that more studies are needed.

Although nitramines have been known for a long time, they have been made mostly for the purpose of making explosives (e.g., 1,3,5-trinitroperhydro-1,3,5-triazine (RDX), Octahydro-1,3,5,7tetranitro-1,3,5,7-tetrazocine (HMX), nitroguanidine and tetryl) and rocket fuels [14,15]. On the other hand, their use in synthesis has been exploited only to a very limited extent. The best example of this is the use of primary nitramines in the Mannich reaction [16].

To learn more about these byproducts, we started a new project aiming for a practical and safe synthesis of pure nitramines. The general method for their syntheses has been to add $70 \%-100 \%$ nitric acid to the corresponding amine. This is a general and fairly efficient method. However, several problems may be encountered with this procedure, such as a lack of chemoselectivity. The use of the obnoxious and highly corrosive concentrated or pure nitric acid is by itself a hazard. Special precautions must be taken to avoid over-nitration, which will pose an increased risk for explosions [17].

One way of avoiding the nitration of the alcohol would, of course, be protection. A simple and efficient protection method for an alcohol is transformation to an ester, usually by adding acetyl chloride or acetic anhydride. However, most of these methods will also give the corresponding amide 
when amino groups are present, primary amines being especially reactive. This will immediately pose two problems: the amide will be less reactive than the amine, and fairly harsh conditions are needed for the deprotection of both the ester and nitrated amide.

The challenge will be to find protection groups that are both stable to the nitration conditions and should either be chemoselective (i.e., not react with the amine) or the protected amine would have to be reactive towards the nitration agent.

Furthermore, the protection group should be removable without affecting the nitramine and to avoid the formation of metal salts of the nitramines, which are quite acidic ( $\left.\mathrm{pK}_{\mathrm{a}} \approx 6\right)$. Metal salts of these are known to be even more prone to detonation, and as such, special precautions have to be taken before handling them [18].

\section{Results and Discussion}

\subsection{MEA Nitramine}

The only synthesis of MEA nitramine (4) described in the literature is a patented procedure in which nitramide is reacted with ethylene oxide [19]. Other than this, the compound is mentioned briefly as an intermediate in a paper from 1953, though no isolation of the compound was reported [20]. The authors made dinitrated MEA followed by hydrolysis and reported that the oxygen-nitro group is hydrolyzed more easily than the nitrogen (Scheme 1).
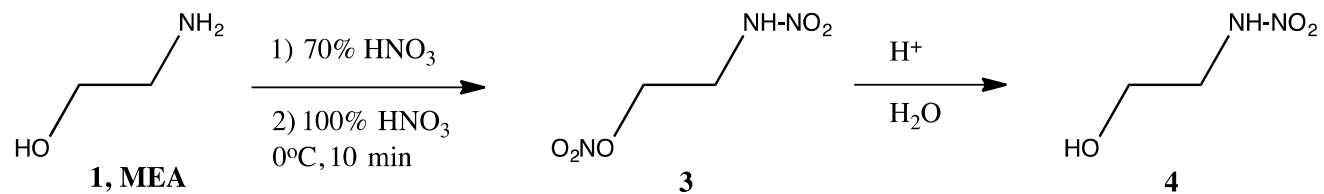

Scheme 1. Possible synthesis of 2-hydroxyethylnitramine [20].

Although this method is an option, the two major drawbacks are (1) the ability to stop the hydrolysis in due time before full hydrolysis occurs as nitramines are unstable in acidic water solutions and, more severely; (2) the dinitrated compound, 2-nitroaminoethyl nitrate, is expected to be even more prone to explosion. However, it was anticipated that the protected MEA, e.g., 2-aminoethyl acetate, could be used; though the ester may hydrolyze under the given nitrating conditions, giving a possibility for the alcohol to be deprotected and nitrated, as well. Although this should be possible to handle by monitoring the hydrolysis reaction, it will still pose a risk.

Another variety of this strategy would be to prepare the nitramines from the corresponding tosylamides [21]. This has worked well in our laboratory, and we decided to try the same strategy for MEA. The acetate of 2-((4-methylphenyl)sulfonamido)ethyl (5) can be prepared using a literature procedure [22]. The strategy is depicted in Scheme 2.

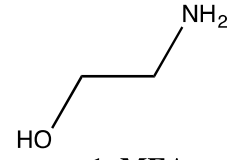

1, MEA
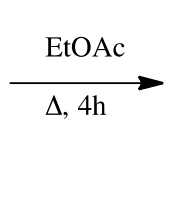

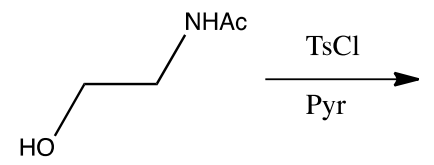

5

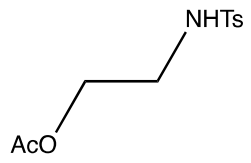

6
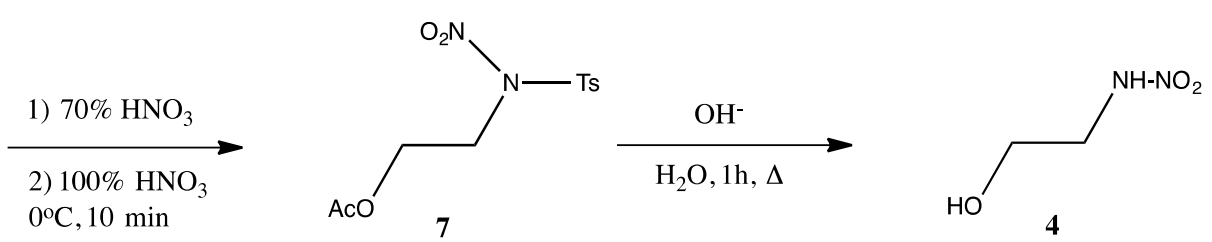

Scheme 2. Attempted synthesis of 2-hydroxyethylnitramine. 
At first, we performed nitration and hydrolysis in one batch without isolating the nitro tosylate intermediate followed by exclusion of nitric acid prior to hydrolysis, but all attempts to do so failed, resulting only in impure samples containing less than $10 \%$ of the title compounds.

Therefore, we decided to isolate the nitro tosylatamide 7 . The classic way to make nitramines is to react an amine with a huge excess of fuming nitric acid, followed by evaporation to dryness on a steam bath [23]. Following this procedure, we managed to obtain the nitro tosylamide 7 in a $70 \%$ yield, but only in an inadequate purity. We decided to try evaporation assisted by a flow of nitrogen gas at room temperature. However, it was not possible to achieve reproducible results comparable to the previous experiments; neither conversion, yield nor purity could be reproduced. Production of obnoxious and corrosive nitrous gases is also a severe disadvantage of such a method.

Different hydrolytic conditions were also attempted, but as this strategy depended on basic hydrolysis, inorganic salts will be present. At best, the NMR analysis implied a mixture consisting of some $70 \%$ of the desired compound. Therefore, this strategy was eventually abandoned.

We still figured some kind of protection would be the best way of synthesizing 2-hydroxyethylnitramine. Starting with commercially-available 2-oxazolidone (8) should be ideal, since hydrolysis of the nitrated compound should give 2-hydroxyethylnitramine (4) with carbonic acid as the only side product. Therefore, we set forth this reaction as depicted in Scheme 3.

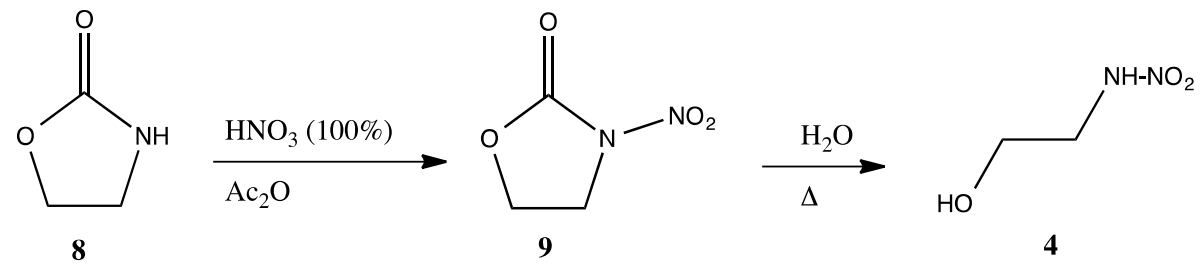

Scheme 3. Synthesis of 2-hydroxyethylnitramine.

The nitration method described above worked out beautifully. Nitramine 9 was obtained as pure after recrystallization with ethanol. We tried to do the hydrolysis in neutral water, and with slight heating, this also worked out smoothly. The product was isolated as the pure compound. It crystallizes at low temperature and can also be recrystallized this way. However, since it is found that the nitrated oxazolidone is much easier to handle, being a high-melting crystalline compound, it is better to stock the compound as such and then hydrolyze it when needed.

However, evaporation of fuming nitric acid as an obnoxious gas is not feasible. Therefore, we were looking for an improvement. One known alternative is the combination of acetic anhydride and nitric acid at low temperature, to give $\mathrm{AcO}-\mathrm{NO}_{2}$, which is known as an effective nitration agent [24]. We used a slight modification on the published procedures by White et al. [25]. The evaporation of fuming nitric acid will henceforth be referred to as Method A, while the latter, employing $\mathrm{AcO}-\mathrm{NO}_{2}$, will be referred to as Method B.

Another alternative is employing copper nitrate in combination with acetic anhydride. We found this method preferable; as it does not use the corrosive fuming nitric acid at all [26]. This method will be referred to as Method C.

All three nitration methods gave the compound in good yield, although Method A gave a slightly better yield than the two other ones.

\subsection{AMP Nitramine}

Strategies similar to the ones illustrated in Schemes 1 and 2 were used on AMP with the same result. With the success making 2-hydroxyethylnitramine via the oxazolidone, we thought the same method would apply to AMP.

Using a modified literature procedure starting from 2-amino-2-methyl-1-propanol (2), we made the corresponding oxazolidone 9 on a large scale in a very good yield [25]. See Scheme 4. 
The same protocols for nitration were used. Method A resulted in a complex mixture of products, and purification gave a drastic drop in the isolated yield, while both Method B and C gave Product 11 in high yields (Table 1, Entry 2), which was easily purified by recrystallization.

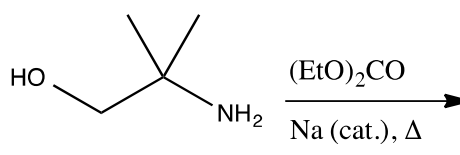

2, AMP<smiles>CC1(C)COC(=O)N1</smiles><smiles>CC(C)(CO)[N+](=O)[O-]</smiles>

Scheme 4. Synthesis of 1-hydroxy-2-methylpropan-2-ylnitramine.

Hydrolysis of the carbamate using the neutral conditions mentioned above did indeed work excellently. Again, we figured that due to the decreased stability of the final, open chain nitramine, it would be more practical to handle the high melting crystalline heterocycle and do the hydrolysis only when the nitramine was needed.

\subsection{Scope and Limitations}

In order to explore the scope and limitations of Method C vs. Methods A and B, we tested all three methods on the carbamates. The structures are shown in Figure 1, and the results are listed in Table 1.
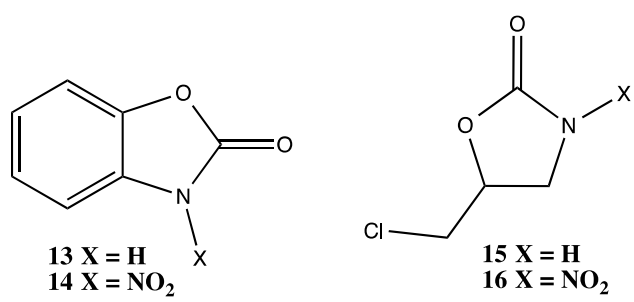<smiles>[Y]N1CCCOC1=O</smiles><smiles>[X]N(C(=O)OC(C)(C)C)[C@@H](C)C(=O)OC</smiles><smiles>[X]N1CCNC1=O</smiles><smiles>[X]N1CCCNC1=O</smiles>

$19 \mathrm{X}=\mathrm{H}$

$21 \mathrm{X}=\mathrm{H}$ $22 \mathrm{X}=\mathrm{NO}_{2}$

Figure 1. Structure of carbamates and cyclic urea derivatives.

For benzo[d]oxazol-2(3H)-one (13), both reactions using nitric acid gave a lower yield of nitramine 14 compared to the one employing $\mathrm{Cu}\left(\mathrm{NO}_{3}\right)_{2}$. This can be explained by the fact that we had purification problems related to the removal of nitric acid. Somehow, we had problems removing all of the nitric acid, and when heated, the mixture exploded, possibly due to nitration of the aromatic ring. 
Table 1. Reaction yield for the different nitration methods on the carbamates compared.

\begin{tabular}{cccccc}
\hline \multirow{2}{*}{ Entry } & Starting Material & \multicolumn{3}{c}{ Yields (\%) } & \multirow{2}{*}{ Product } \\
\cline { 3 - 4 } & & A & B & C & \\
\hline 1 & 2-oxazolidone (9) & 78 & 65 & 59 & $\mathbf{4}$ \\
2 & 4,4-dimethyloxazolidin-2-one (10) & 43 & 63 & 62 & $\mathbf{1 1}$ \\
3 & benzo[d]oxazol-2(3H)-one (13) & 54 & 32 & 74 & $\mathbf{1 4}$ \\
4 & 5-(chloromethyl)-oxazolidin-2-one (15) & 69 & 70 & 54 & $\mathbf{1 6}$ \\
5 & 1,3-oxazinan-2-one (17) & 56 & 59 & 62 & $\mathbf{1 8}$ \\
6 & Methyl (tert-butoxycarbonyl)alaninate (19) & - - a & - - a & 52 & $\mathbf{2 0}$ \\
\hline
\end{tabular}

Yields are listed for pure material, i.e., after recrystallization. ${ }^{a}$ Resulted in a complex mixture, with no traces of desired product according to NMR.

For 5-(chloromethyl)-oxazolidin-2-one (15), Method $C$ gave a lower yield of nitramine $\mathbf{1 6}$ compared to Method A and B. This is probably due to some competitive reaction with the halogen and copper in Method C.

Nitration of 1,3-oxazinan-2-one (17) gave approximately the same yield of nitramine $\mathbf{1 8}$ with all three methods.

We know that the non-cyclic carbamates, e.g., Boc-protected amines, will be cleaved when treated with strong acids (e.g., $\mathrm{HCl}$ or $\mathrm{CF}_{3} \mathrm{CO}_{2} \mathrm{H}$ ), and we were expecting the same thing to happen under the conditions of Method $\mathrm{B}$ and $\mathrm{C}$. That was also what we observed when methyl(tert-butoxycarbonyl)alaninate (19) was attempted to be nitrated. The reactions led to complex mixtures, and the desired nitramine $\mathbf{2 0}$ was not observed at all. Conversely, using Method C gave the desired nitramine in an acceptable yield, as listed in Table 1, Entry 6.

To extend the potential of the reaction, we also tried to mononitrate the bisamines using the corresponding cyclic urea derivatives. Obviously, the number of equivalents had to be changed to avoid over nitration. Method A was abandoned, since it was anticipated to give a mixture of mono- and di-substituted products together with unreacted material. A preliminary experiment confirmed this. Method B gave the mononitramine of structure imidazolidin-2-one (22) and tetrahydropyrimidin-2(1H)-one (24) in yields of $60 \%$ and $70 \%$, respectively. However, it was discovered that a published synthesis of 1-nitroimidazolidin-2-one uses similar conditions, but at room temperature in a shorter reaction time [27]. Employing the already published conditions, we synthesized 1-nitrotetrahydropyrimidin-2(1H)-one in a good yield $(70 \%)$.

Method $\mathbf{C}$ was tested on the same urea derivatives, but the yield was extremely poor. Increasing the amount of $\mathrm{Cu}\left(\mathrm{NO}_{3}\right)_{2}$ gave a mixture of mono- and di-substituted products together with unreacted material.

\section{Materials and Methods}

General: All reagents and solvents were commercial grade and used without further purification. The NMR spectra were recorded on a Varian Gemini 300 (Varian Inc., Palo Alto, CA, USA) or a Bruker AVANCE 400 spectrometer (Bruker Corporation, Billerica, MA, USA). IR spectra were obtained on a reflectance cell (HATR) on a Perkin Elmer FTIR instrument (PerkinElmer, Inc., Waltham, MA, USA). High resolution mass spectra were obtained for 2-hydroxyethylnitramine and 1-hydroxy-2-methylpropan-2-ylnitramine using an Agilent 1100 liquid chromatography system (Agilent Technologies, Waldbronn, Germany), equipped with an Agilent 1100 auto-sampler, an Agilent 1100 quaternary pump, an Agilent 1100 on-line degassing system and an Agilent 1100 diode array detector (UV). The analytical detector was a Micromass LCT orthogonal-acceleration time-of-flight (TOF) mass spectrometer (MS) equipped with a Z-spray electrospray ion source and a 4-GHz time to digital converter (TDC) (Waters Corporation, Milford, MA, USA). NMR and IR spectra can be found in "Supplementary Materials". 
In particular handling of concentrated and fuming nitric acid $\left(\mathrm{HNO}_{3}\right)$ needs special precautions and safety equipment. Furthermore, all nitrated compounds should be treated as potential explosives.

\subsection{General Nitration Procedures}

\subsubsection{Method A}

The carbamate (115 mmol) was added portion wise to stirred nitric acid (100\%; $28 \mathrm{~g} ; 444 \mathrm{mmol})$. The solution was evaporated to dryness on a steam bath. The product solidified on cooling; it was dried in vacuo and recrystallized from toluene (absolute. ethanol can also be used) to give the product.

\subsubsection{Method B}

Using a dry ice/acetone bath acetic anhydride $(25 \mathrm{~mL})$ was cooled to $-15^{\circ} \mathrm{C}$. Fuming nitric acid (18.5 g; $13.2 \mathrm{~mL} ; 298 \mathrm{mmol}$ ) was added dropwise keeping the temperature between -10 and $-15^{\circ} \mathrm{C}$. A mixture of the carbamate $(24.0 \mathrm{mmol})$ and about $12.5 \mathrm{~mL}$ of $\mathrm{Ac}_{2} \mathrm{O}$ was added slowly at $-15^{\circ} \mathrm{C}$ with vigorous stirring. The mixture was allowed to warm up to $0{ }^{\circ} \mathrm{C}$ and maintained at $0-4{ }^{\circ} \mathrm{C}$ for $10 \mathrm{~h}$. The reaction mixture was poured on ice and stirred for a couple of minutes. Extraction with DCM, washing with $10 \% \mathrm{NaHCO}_{3}$, drying $\left(\mathrm{MgSO}_{4}\right)$ and evaporation yielded the product.

\subsubsection{Method C}

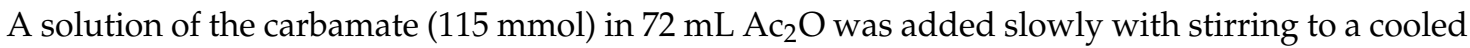
$\left(5-10^{\circ} \mathrm{C}\right)$ suspension of finely-ground $\mathrm{Cu}\left(\mathrm{NO}_{3}\right)_{2} \cdot\left(\mathrm{H}_{2} \mathrm{O}\right)_{3}(10.5 \mathrm{~g} ; 43 \mathrm{mmol})$ in $85 \mathrm{~mL} \mathrm{Ac} 2 \mathrm{O}$. After $1 \mathrm{~h}$, an additional portion of finely-ground $\mathrm{Cu}\left(\mathrm{NO}_{3}\right)_{2} \cdot\left(\mathrm{H}_{2} \mathrm{O}\right)_{3}(10.5 \mathrm{~g} ; 43 \mathrm{mmol})$ was added. The resulting mixture was cooled to $0-5^{\circ} \mathrm{C}$ (ice/water) and stirred for another $4 \mathrm{~h}$ while slowly being heated to room temperature. The mixture was filtered through Celite 545 . Water $(50 \mathrm{~mL})$ was added, and the water phase was extracted with DCM $(3 \times 50 \mathrm{~mL})$ to get rid of additional dissolved copper salts. Drying $\left(\mathrm{MgSO}_{4}\right)$ and evaporation gave a crystalline compound that was recrystallized from toluene to give the product.

\subsection{Spectral Data}

3-Nitrooxazolidin-2-one (9): Oxazolidin-2-one (8) was nitrated using Methods A, B and C to give 9 as off-white crystals. m.p. $109-110{ }^{\circ} \mathrm{C}$ (literature. ${ }^{1}$ m.p. $\left.108-109.5^{\circ} \mathrm{C}\right) .{ }^{13} \mathrm{C}-\mathrm{NMR}\left(100 \mathrm{MHz}, \mathrm{CDCl}_{3}\right)$ : $\delta 45.22,60.18,147.45 .{ }^{1} \mathrm{H}-\mathrm{NMR}\left(400 \mathrm{MHz}, \mathrm{CDCl}_{3}\right): \delta 4.39(2 \mathrm{H}, \mathrm{d}, J=7.2 \mathrm{~Hz}), 4.32(2 \mathrm{H}, J=7.2 \mathrm{~Hz})$. IR: $3006,1794,1565 \mathrm{~cm}^{-1}$.

4,4-Dimethyl-3-nitrooxazolidin-2-one (11): 4,4-dimethyloxazolidin-2-one (10) was nitrated using Methods A, B and C to give 11 as white crystals. m.p. $121-122{ }^{\circ} \mathrm{C}$ (lit. .1 m.p. $\left.124{ }^{\circ} \mathrm{C}\right) .{ }^{13} \mathrm{C}-\mathrm{NMR}\left(100 \mathrm{MHz}, \mathrm{CDCl}_{3}\right)$ : $\delta$ 22.02, 62.92, 72.18, 147.65. ${ }^{1} \mathrm{H}-\mathrm{NMR}\left(400 \mathrm{MHz}, \mathrm{CDCl}_{3}\right): \delta 4.11(6 \mathrm{H}, \mathrm{s}), 1.68(2 \mathrm{H}, \mathrm{s})$. IR: 3005, 2992, $2949,1772,1565 \mathrm{~cm}^{-1}$.

3-Nitrobenzo[d]oxazol-2(3H)-one (14): Benzo[d] oxazol-2(3H)-one (13) was nitrated using Methods A, $\mathrm{B}$ and $\mathrm{C}$ to give 19 as white crystals, slightly yellow. m.p. was not determined, as the compound decomposed on the apparatus. ${ }^{13} \mathrm{C}-\mathrm{NMR}\left(100 \mathrm{MHz}, \mathrm{CD}_{3} \mathrm{OD}\right): \delta 109.32,114.93,130.11,132.73,141.52$, 145.38, 153.99. ${ }^{1} \mathrm{H}-\mathrm{NMR}\left(400 \mathrm{MHz}, \mathrm{CD}_{3} \mathrm{OD}\right): \delta 8.44(2 \mathrm{H}, \mathrm{d}, J=1.8 \mathrm{~Hz}), 8.86(2 \mathrm{H}, \mathrm{d}, J=1.8 \mathrm{~Hz})$. IR: 3103, $1798,1637,1543 \mathrm{~cm}^{-1}$.

5-(Chloromethyl)-3-nitrooxazolidin-2-one (16): 5-(chloromethyl)oxazolidin-2-one (15) was nitrated using Methods A, B and C to give $\mathbf{2 1}$ as white crystals. m.p. was not determined, as the compound decomposed on the apparatus. ${ }^{13} \mathrm{C}-\mathrm{NMR}\left(100 \mathrm{MHz}, \mathrm{CDCl}_{3}\right): \delta 42.77,47.50,70.14,146.45 .{ }^{1} \mathrm{H}-\mathrm{NMR}$ $\left(400 \mathrm{MHz}, \mathrm{CDCl}_{3}\right): \delta 3.69-3.80(2 \mathrm{H}, \mathrm{m}), 4.25(1 \mathrm{H}, \mathrm{dd}, J=5.9 \mathrm{~Hz}, J=4.3 \mathrm{~Hz}), 4,42(\mathrm{dd}, J=8.5 \mathrm{~Hz}$, $J=4.3 \mathrm{~Hz}), 4.81-4.87(1 \mathrm{H}, \mathrm{m})$. IR: 3025, 2968, 2929, 2853, 1804, $1571 \mathrm{~cm}^{-1}$. 
3-Nitro-1,3-oxazinan-2-one (18): 1,3-oxazinan-2-one (17) was nitrated using Methods A, B and C to give 21 as off-white crystals. m.p. $75-76{ }^{\circ} \mathrm{C}$ (lit. $\left.{ }^{1} 74{ }^{\circ} \mathrm{C}\right) .{ }^{13} \mathrm{C}-\mathrm{NMR}\left(100 \mathrm{MHz}, \mathrm{CDCl}_{3}\right): \delta 22.56,47.77,66.88$, 146.52. ${ }^{1} \mathrm{H}-\mathrm{NMR}\left(400 \mathrm{MHz}, \mathrm{CDCl}_{3}\right): \delta 2.24(2 \mathrm{H}, \mathrm{m}), 4.12(2 \mathrm{H}, \mathrm{t}, J=6.7 \mathrm{~Hz}), 2.24(2 \mathrm{H}, \mathrm{t}, J=5.5 \mathrm{~Hz})$. IR: $1802,1572 \mathrm{~cm}^{-1}$.

Methyl N-(tert-butoxycarbonyl)-N-nitro-alaninate (20): Methyl N-(tert-butoxycarbonyl)-alaninate (19) was nitrated using Method $\mathrm{C}$ to give 22 as a white/clear oil. ${ }^{13} \mathrm{C}-\mathrm{NMR}\left(100 \mathrm{MHz}, \mathrm{CDCl}_{3}\right): \delta 14.16,27.72$, 52.77, 56.64, 86.65, 148.67, 169.20. ${ }^{1} \mathrm{H}-\mathrm{NMR}\left(400 \mathrm{MHz}, \mathrm{CDCl}_{3}\right): \delta 1.55(9 \mathrm{H}, \mathrm{s}), 1.61(3 \mathrm{H}, \mathrm{d}, J=7.0 \mathrm{~Hz})$, $3.76(3 \mathrm{H}, \mathrm{s}), 5.22(1 \mathrm{H}, \mathrm{q}, J=7.0 \mathrm{~Hz})$. IR: 2986, 1749, 1582.

1-Nitrotetrahydropyrimidin-2(1H)-one (24): Tetrahydropyrimidin-2(1H)-one (23) was nitrated a modification of Methods B, as described by Astakhov et al. [20], to give 23 as white crystals. ${ }^{13} \mathrm{C}-\mathrm{NMR}(100 \mathrm{MHz}$, $\left.\mathrm{CDCl}_{3}\right): \delta 150.28,22.49 ., 39.84,48.20 .{ }^{1} \mathrm{H}-\mathrm{NMR}\left(400 \mathrm{MHz}, \mathrm{CDCl}_{3}\right): \delta 6.37(1 \mathrm{H}, \mathrm{bs}), 4.12(2 \mathrm{H}, \mathrm{t}, J=6.2 \mathrm{~Hz})$, $3.37(2 \mathrm{H}, \mathrm{m}), 2.17(2 \mathrm{H}, \mathrm{q}, J=6.2 \mathrm{~Hz})$. IR: 1694, $1532 \mathrm{~cm}^{-1}$.

\section{Conclusions}

We have tested and compared three methods for the nitration of amino alcohols. Method $\mathrm{C}$ has proven to be a reliable and safe alternative to the classic Methods A and B when an excess of the $\mathrm{NO}_{2}{ }^{+}$-source can be tolerated. Nitration of more sensitive compounds (e.g., Boc-protected alanine ethyl ester) was also possible with this protocol, but mono-nitration on diamines does not work.

Supplementary Materials: Supplementary materials can be accessed at: http:/ /www.mdpi.com/1420-3049/21/ 12/1738/s1.

Acknowledgments: Thanks to Ivar Skiaker for help during preliminary experiments.

Author Contributions: Y.S. and M.A. conceived of and designed the experiments. S.A., M.A. and H.G.-S. performed the experiments. C.D. analyzed the data. Y.S. and S.A wrote the paper.

Conflicts of Interest: The authors declare no conflict of interest.

\section{References}

1. Walters, M.S.; Edgar, T.F.; Rochelle, G.T. Regulatory Control of Amine Scrubbing for $\mathrm{CO}_{2}$ Capture from Power Plants. Ind. Eng. Chem. Res. 2016, 55, 4646-4657. [CrossRef]

2. Rochelle, G.T. Amine Scrubbing for $\mathrm{CO}_{2}$ Capture. Science 2009, 325, 1652-1654. [CrossRef] [PubMed]

3. Dai, N.; Shah, A.D.; Hu, L.; Plewa, M.J.; McKague, B.; Mitch, W.A. Measurement of Nitrosamine and Nitramine Formation from NOx Reactions with Amines during Amine-Based Carbon Dioxide Capture for Postcombustion Carbon Sequestration. Environ. Sci. Technol. 2012, 46, 9793-9801. [CrossRef] [PubMed]

4. Rochelle, G.T.; Fine, N.A. Absorption of Nitrogen Oxides in Aqueous Amines. Energy Procedia 2014, 63, 830-847.

5. Helgesen, L.I.; Gjernes, E. A way of qualifying Amine Based Capture Technologies with respect to Health and Environmental Properties. Energy Procedia 2016, 86, 239-251. [CrossRef]

6. Coutris, C.; Macken, A.L.; Collins, A.R.; Yamani, N.; Brooks, S.J. Marine ecotoxicity of nitramines, transformation products of amine-based carbon capture technology. Sci. Total Environ. 2015, 527-528, 211-219. [CrossRef] [PubMed]

7. Buist, H.E.; Devito, S.; Goldbohm, R.A.; Stierum, R.H.; Venhorst, J.; Kroese, E.D. Hazard assessment of nitrosamine and nitramine by-products of amine-based CCS: Alternative approaches. Regul. Toxicol. Pharmacol. 2015, 71, 601-623. [CrossRef] [PubMed]

8. Gundersen, C.B.; Andersen, T.; Lindahl, S.; Linke, D.; Vogt, R.D. Bacterial response from exposure to selected aliphatic nitramines. Energy Procedia 2014, 63, 791-800. [CrossRef]

9. Nielsen, C.J.; Herrmann, H.; Weller, C. Atmospheric chemistry and environmental impact of the use of amines in carbon capture and storage (CCS). Chem. Soc. Rev. 2012, 41, 6684-6704. [CrossRef] [PubMed]

10. Nielsen, C.J.; D’Anna, B.; Dye, C.; Graus, M.; Karl, M.; King, S.; Maguto, M.M.; Müller, M.; Schmidbauer, N.; Stenstrøm, Y.; et al. Atmospheric chemistry of 2-aminoethanol (MEA). Energy Procedia 2001, 4, 2245-2252. [CrossRef] 
11. Wagner, E.D.; Osiol, J.; Mitch, W.A.; Plewa, M.J. Comparative in vitro toxicity of nitrosamines and nitramines associated with aminebased carbon capture and storage. Environ. Sci. Technol. 2014, 48, 8203-8211. [CrossRef] [PubMed]

12. Dai, N.; Mitch, W.A. Effects of flue gas compositions on nitrosamine and nitramine formation in postcombustion $\mathrm{CO}_{2}$ capture systems. Environ. Sci. Technol. 2014, 48, 7519-7526. [CrossRef] [PubMed]

13. Pitts, J.N.; Grosjean, D.; Vancauwenberghe, K.; Schmid, J.P.; Fitz, D.R. Photo-oxidation of aliphatic-amines under simulated atmospheric conditions-formation of nitrosamines, nitramines, amides, and photo-chemical oxidant. Environ. Sci. Technol. 1978, 12, 946-953. [CrossRef]

14. Beckstead, M.W.; Puduppakkam, K.; Thakre, P.; Yang, V. Modeling of combustion and ignition of solid-propellant ingredients. Prog. Energy Combust. Sci. 2007, 33, 497-551. [CrossRef]

15. Sikder, A.K.; Maddala, G.; Agrawal, J.P.; Singh, H. Important aspects of behaviour of organic energetic compounds: A review. J. Hazard. Mater. 2001, 84, 1-26. [CrossRef]

16. Buckle, D.R.; Pinto, I.L. 4.09-Functions Bearing Two Nitrogens. In Comprehensive Organic Functional Group Transformations; Katritzky, A.R., Meth-Cohn, O., Rees, C.W., Eds.; Elsevier Science: Oxford, UK, 1995; pp. 403-449; ISBN: 9780080447056.

17. Agrawal, J.P.; Hodgson, R.D. Organic Chemistry of Explosives; Wiley: New York, NY, USA, 2007; ISBN: 978-0-470-02967-1.

18. Matyáš, R.; Pachman, J. Primary Explosives; Springer: Berlin, Germany, 2013; pp. 325-328; ISBN: 978-3-642-28435-9.

19. Jianming, Y.; Lv, J.; Yu, Q.; Li, F.; Liu, B.; Wang, W. Method for Preparing N-Nitroamino Alcohol. CN 101973908 A, 16 February 2011.

20. Barrott, J.; Denton, I.N.; Lamberton, A.H. Nitramines and nitramides. Part IV. The acid-catalysed decomposition of primary nitramines. J. Chem. Soc. 1953, 1998-2005. [CrossRef]

21. Yamaguchi, T.; Hesek, D.; Lee, M.; Oliver, A.G.; Mobashery, S. Sulfonylation-induced N- to O-acetyl migration in 2-acetamidoethanol derivatives. J. Org. Chem. 2010, 75, 3515-3517. [CrossRef] [PubMed]

22. Maguta, M.M.; Aursnes, M.; Bunkan, A.J.C.; Edelen, K.; Mikoviny, T.; Nielsen, C.J.; Stenstrom, Y.; Tang, Y.; Wisthaler, A. Atmospheric fate of nitramines: An experimental and theoretical study of the $\mathrm{OH}$ reactions with $\mathrm{CH}_{3} \mathrm{NHNO}_{2}$ and $\left(\mathrm{CH}_{3}\right)_{2} \mathrm{NNO}_{2}$. J. Phys. Chem. 2014, 118, 3450-3462. [CrossRef] [PubMed]

23. Franchimont, A.P.N.; Lublin, A. Nitroamino-alcohols. Rec. Trav. Chim. 1902, 21, 45-55.

24. Bordwell, F.G.; Garbisch, E.W. Nitrations with acetyl nitrate. I. The nature of the nitrating agent and the mechanism of reaction with simple alkenes. J. Am. Chem. Soc. 1960, 82, 3588-3598. [CrossRef]

25. White, E.H.; Chen, M.C.; Dolak, L.A. N-nitroamides and N-nitrocarbamates. III. Rotational isomerism, steric effects, and physical properties at low temperatures. J. Org. Chem. 1966, 31, 3038-3046. [CrossRef]

26. Menke, J.B. Nitration with nitrates. Recl. Travaux Chim. Pays-Bas 1925, 44, 141-149. [CrossRef]

27. Astakhov, M.; Stepanov, R.S.; Kruglyakova, L.A.; Kekin, Y.V. 1-Nitroimidazolidin-2-one and its hydrolysis to 1-amino-2-nitroaminoethane. Russ. J. Org. Chem. 2000, 36, 575-576.

Sample Availability: Samples of the compounds 9, 11, 14, 16, 8, 10 and 24 are available from the authors.

(C) 2016 by the authors; licensee MDPI, Basel, Switzerland. This article is an open access article distributed under the terms and conditions of the Creative Commons Attribution (CC-BY) license (http://creativecommons.org/licenses/by/4.0/). 